\title{
Correction to: Potatoes, Nutrition and Health
}

\author{
Katherine A. Beals ${ }^{1,2}$
}

Published online: 10 April 2019

(C) The Author(s) 2019

\section{Correction to: American Journal of Potato Research https://doi.org/10.1007/s12230-018-09705-4}

In the original article the author's affiliations were incomplete and conflict of interest disclosure was missing. The author discloses that she is a paid consultant for Fleishman-Hillard, Inc, whose clients include Potatoes USA.

The online version of the original article can be found at https://oi.org/ 10.1007/s12230-018-09705-4

Katherine A. Beals

katherine.beals@hsc.utah.edu

1 Department of Nutrition and Integrative Physiology, University of Utah, Salt Lake City, UT, USA

2 Fleishman-Hillard, Sacramento, CA, USA 